Article

\title{
How to Communicate Lateran IV in 13th Century Ireland: Lessons from the Liber Exemplorum (c.1275)
}

\author{
Salvador Ryan ${ }^{1, *}$ and Anthony Shanahan ${ }^{2}$ \\ 1 Faculty of Theology, Pontifical University, St Patrick's College, Maynooth, Co. Kildare W23 TW77, Ireland \\ 2 Independent, Thurles E41 FR98, Ireland; antoinoseanachain@hotmail.com \\ * Correspondence: salvador.ryan@spcm.ie; Tel.: +353-1-708-3972
}

Received: 11 January 2018; Accepted: 2 March 2018; Published: 9 March 2018

\begin{abstract}
The Liber Exemplorum, a collection of preachers' tales, was compiled c.1275 by an English Franciscan working in Ireland, and is the earliest Franciscan example of its type. Out of 213 exempla which survive in this manuscript, some 26 of these are found in no other source, and are drawn either from the compiler's own experience or from his having heard of them second hand; these often mention Irish place names and feature Irish Christians as the main protagonists. The collection was compiled some 60 years after the calling of the Fourth Lateran Council, whose decrees would significantly shape the lives of medieval Christians for centuries. This article examines the manner in which some of the principal concerns of Lateran IV appear prominently as themes in this collection of preachers' tales, and, furthermore, how such tales played a crucial role in the popular dissemination of the reforms envisaged by the council fathers. The tales themselves also offer a unique window on popular religious practice and ideas, both real and imagined, in late-13th-century Ireland.
\end{abstract}

Keywords: Fourth Lateran Council; Lateran IV; preaching; Eucharist; Penance; exempla; clergy; Ireland; Franciscan; Virgin Mary

\section{Introduction}

November 2015 marked the 800th anniversary of one of the great councils of the Middle Ages, the Fourth Lateran Council, called by arguably the most powerful of medieval popes, Innocent III, whose reign from 1198 to 1216 marked the culmination of one of the great reforming papacies. While well known for involving himself heavily in the dynastic politics of his day, intervening in disputes in Norway, Sweden, Bohemia and Hungary, not to mention succession crises concerning German emperors, Innocent was a church reformer at heart, and Lateran IV represents the realisation of many of his own reforming projects and ideals. Innocent made sure to allow plenty of time to prepare for the Council—a full two and a half years-having announced it in April 1213. The letter of summons which he sent to would-be delegates set out the Council's stall as follows: it was being called to "eradicate vices and plant virtues, to correct faults and reform morals, to remove heresies and strengthen faith, to settle discords and establish peace, to get rid of oppression and foster liberty, [and] to induce princes and Christian people to succour the Holy Land" (Tanner 2000, p. 113). The Council was preceded by local fact-finding exercises and bishops were invited to send in their suggestions regarding what needed to be reformed. The Council met in three sessions (11 November, 20 November and 30 November) and issued 70 decrees. It was attended by 404 bishops and some 800 abbots, priors and representatives from cathedral chapters and collegiate churches.

Among many other issues, the Council is particularly remembered for intervening on a late-11th-century dispute between Berengar of Tours and Archbishop Lanfranc of Canterbury on the exact nature of Christ's presence in the Eucharist—did the elements of bread and wine change or not? Lateran IV was the first council to speak of the bread being "transubstantiated" (transsubstantiatis) 
into the body and the wine into the blood by the divine power, as found in its first decree (or canon), Firmiter (Tanner 1990, vol. 1, p. 230). ${ }^{1}$ Although not defining the mechanics of transubstantiation itself, this endorsement was to have a seismic effect on lay devotion to the Mass in the later Middle Ages and, in addition, greatly elevated the role of the priest in the popular mindset. More than anything else, though, Lateran IV is remembered for the wider revolution in pastoral care which it supported, promoted and legislated for and which, in the words of Thomas M. Izbicki, "formed the foundation of synodal legislation and pastoral care as far from Rome as Cyprus, Germany and Moravia" ((Izbicki 2015, p. 148); some of this synodal legislation went further than the decrees of the Council itself. So, for example, local diocesan statutes at York and Carlisle mandated that not just the Eucharistic hosts, but also church ornaments, books and vestments be kept under lock and key (Birkett 2006, p. 204)). This can most notably be observed in its 21st decree, Omnis utriusque sexus, which mandated the reception of the Sacrament of Penance and Eucharist at least once a yearwhich led, in turn, to the recognition of a need for more competent clergy to administer pastoral care, tying in with Innocent's hopes for the better education of beneficed clergy who were now to be offered free gratis instruction in theology by cathedral chancellors. In examining what, if anything, was novel in this legislation, Martin Ohst concludes that the clauses which call for confession "to one's one priest" (proprio sacerdoti) and which underline the secrecy of confession were not themselves new; what was new, however, was the obligation to receive the sacrament on an annual basis, and that this obligation extended beyond priests and monks to include all the lay faithful (see Ohst 1995, pp. 32ff). In an English context, Helen Birkett has argued that "although the reforming agenda had been present in the English church before the Council it was only in the years after 1215 that this was translated into an effective, almost nationwide, programme", thus underlining its significance. (See Birkett 2006, p. 199).

More fundamentally still, in an age when heaven was widely thought to be populated almost exclusively by monks, nuns and others who had renounced the world, Lateran IV noted in its first decree that "not only virgins and the continent but married persons find favour with God by right faith and good actions and deserve to attain to eternal blessedness" (Tanner 1990, vol. 1, p. 231). Existence within the world rather than apart from it could now be considered to be a viable path to personal holiness and, ultimately, to salvation. This would open up new vistas of opportunity (and responsibility) for medieval laity and clergy alike. Lay persons need no longer expect to attain heaven solely on the coat-tails of the masses and prayers offered by consecrated monks and clergy. Canon 27 of the Council famously recognised the care of souls as "the art of arts" and thus the clergy themselves were expected to raise their own standards, both in terms of their personal behaviour and the pastoral care they offered (see Reeves 2013). The regulations by which they were to abide, according to canon 16, included wearing clerical tonsure, avoiding dressing in bright colours such as red and green, eschewing taverns, drinking contests and games of dice, avoiding watching mimes, entertainers and actors, and refraining from indulging in commerce (Tanner 1990, vol. 1, p. 243). Helen Birkett remarks that thus, "separate from the laity in appearance, they were also to be separate from the laity in behaviour" (Birkett 2006, p. 201). Furthermore, canon 17 complains of clergy, even higher clergy, who "pass almost the half the night in unnecessary feasting and forbidden conversation, not to mention other things, and leaving what is left of the night for sleep, they are barely roused at the dawn chorus of the birds and pass away the entire morning in a state of stupor" (Tanner 1990, col. 1, p. 243).

There was a relatively large Irish representation at the Fourth Lateran Council, which included 18 bishops and two bishops elect; of these, about a third were Anglo-Norman and two-thirds native Irish (Warren 1997, pp. 1-17; Dunning 1961). In his 1961 essay on this topic, P.J. Dunning remarked that "to complete the picture of the Irish Church and the Lateran Council", work was still needed on the subject of the implementation of Lateran IV in the Ireland of the early 13th century, but in the same

1 For the most recent Latin edition of the decrees of Lateran IV, see (García y García et al. 2013). 
breath lamented that the problem of insufficient extant sources remained (Dunning 1961, p. 112). ${ }^{2}$ While acknowledging the dearth of sources to properly undertake such a study, this article focuses on a single source that, in its own way, yields important insights into how many of the concerns reflected in the decrees of the Fourth Lateran Council might have been re-packaged and communicated to a lay audience in the latter half of the 13th century with the aim that these would be received, appropriated and put into practice. The source in question is a preacher's handbook, the Liber Exemplorum (or book of exempla) compiled between 1275 and 1279 by a Franciscan, originally from Warwickshire, in England, but who spent much of his life in Ireland, and the manuscript is now preserved, albeit incomplete, in Durham Cathedral library. It is the earliest Franciscan example of its type (Jones 2011, pp. 9-11) and one of the most complete and substantial works of its genre from this period (Fletcher 2001, p. 70).

The production of preaching aids has a much earlier history than the 13th century, but the enormous explosion in popular preaching from the 13th century onwards, in particular occasioned by the rise of mendicant orders such as the Franciscans and Dominicans, led to the production of such collections on "an almost industrial scale" ((Jones 2011, p. 5); for the mendicants in medieval Ireland, see (Ó Clabaigh 2012)). Preaching was a lynchpin of Franciscan education, and the cornerstone of a friar's ministry thereafter was to be the preaching of sound doctrine and morals to the laity (D'Avray 1985, p. 82). Exempla, or moralising stories, thus became an indispensable feature of a preacher's arsenal, and were designed to first, capture the attention of his audience, and, secondly, to drive home whatever particular doctrinal, catechetical or moral point that the preacher was attempting to make, in such a way that the congregation would recall it easily (see especially (Bremond et al. 1996); also (Welter 1927)). Indeed, the Augustinian canon and sermon-writer, Alexander of Ashby in Northamptonshire (d. 1208/14), recommended that the good preacher ought to expound "some sweet allegory and narrate some humorous exemplum, that the profoundness of the allegory may delight the educated and the levity of the exemplum might edify the simple, so that each of them may have something to take away" (Campbell 2018, p. 112).

Exempla were not, in themselves, new, as they were used frequently by earlier Church Fathers and, indeed, appear in accounts of the sayings of the Desert Fathers. The Cistercians, too, had produced some important exempla collections in the 12th and 13th centuries, but their heyday would come with the advent of the preaching orders and the new impetus in favour of popular preaching. However, although new exempla collections were now required, their compilers did not necessarily jettison the older exempla found in earlier works; indeed, those that were still found to be useful were incorporated into the newer collections, to be joined by more recently compiled tales (this should not, of course, be taken to mean that some of these re-cycled tales cannot be considered as forming part of the wider reform programme of the late 11th through 13th centuries on the basis of their pre-dating this period of pastoral renewal. It was not unusual for material such as this to be re-presented to lay Christians "in a new key", as it were; besides, the sermon and its content was quite a malleable thing in the Middle Ages. The Dominican, Jacapo Passavanti, while preaching in Florence in 1340-1, wrote in his model sermons that "the reader can cut them up again at will, as he shall desire and as the time and the place and the nature of his audience demands" ((Reeves 2015, pp. 119-20). For an early

2 The work of historians such as Flanagan (2013) and, more recently, Ó Corráin (2017) has examined movements towards the reform of the Irish Church which preceded the Fourth Lateran Council (so, principally in the late eleventh and twelfth centuries). In the latter case, Ó Corráin's principal concern is to argue that the Irish hierarchy's support of the reform movement was an unmitigated disaster for the Irish Church, stripping its ancient monasteries of their assets, imposing a diocesan structure and naively acquiescing to an ill-informed and politically-driven characterization of Irish Christians as barbarian in their practices, which ultimately facilitated the ceding of Irish sovereignty to the Angevin empire. All this was done, he argues, "in the interest of an international mother church and an unrealistic programme of perceived moral betterment" (Ó Corráin 2017, p. 116). Flanagan's work takes quite a different view, setting itself the task of moving "beyond the predominant focus on institutional restructuring" and presenting an analysis of "the impact of the reform agenda on the ideology of episcopal leadership and on lay society" (Flanagan 2013, p. xii). 
modern example of the re-appropriation of older catechetical/penitential material and its use in a changed religious landscape, see (Ryan 2014)). In the Franciscan collection examined here, out of 213 exempla which survive (the original total might well have been at least twice that amount), 38 of these are taken from the Lives of the Desert Fathers, 14 are taken from the Dialogues of Gregory the Great, and 8 are from the works of Augustine of Hippo. Closer to the compiler's own day (and closer, geographically to Ireland) was the Gemma Ecclesiastica (Jewel of the Clergy) of Giraldus Cambrensis (Gerald of Wales), which was written in 1197, and from which the compiler takes 28 stories. Most significantly of all, 26 of the tales featured in the Liber Exemplorum are found in no other source for the author cites these from his own experience or as having been heard personally from another source. In both of these cases, one finds reference to Irish place names and personal names, but there are other instances in which the author tells us he heard a particular tale from a friar in Paris; from an Italian friar; from a friar who was present at the siege of Seville; or from a Danish friar who was on a visit to Dublin (Jones 2011, pp. 7-11). Such incidental references tell us much about the importance of the international network of Franciscans and how such preachers' tales were related, adopted, and re-circulated across Europe over relatively short periods of time. Andrew Reeves remarks that "the preaching heard in Parisian university-based sermons often formed the basis of model sermon collections [which] informed those same friars who would eventually end up in the convents of their respective homelands" (Reeves 2015, p. 114). In tale 38, the compiler of the Liber Exemplorum specifically tells us that he spent time in Paris and that he met the well-known Franciscan scholar-scientist, Roger Bacon, while he was there (Jones 2011, p. 10).

This article pays particular attention to the content of the tales themselves and what that content reveals about the perceived state of lay religious practice and ideas in 13th century Ireland. It approaches this from two perspectives: first, what the tales and their selection are responding to in the context of the programme of reform within the Church which culminated in the Fourth Lateran Council some 60 years earlier; and secondly, albeit in lesser detail, how these tales, and others like them (and the ideas they contained) may have succeeded in shaping and influencing popular religious practice in Ireland in succeeding centuries. In doing so, however, it acknowledges, with Andrew Reeves, that "not even exempla are a truly unmediated window into daily life. Being drawn up in collections for the use of clergy by clergy, these exempla may very well reflect the needs and preconceptions of their clerical users" (Reeves 2015, p. 179). While there were numerous other concerns which constituted the Council's 70 decrees (far more than those cited above), for the purposes of this article three principal areas are examined in the light of the Liber Exemplorum: first, an emphasis on the real, transubstantiated presence of Christ in the Eucharist, and the proper disposal with which one should approach the sacrament; secondly, the necessity of receiving the Sacrament of Penance from one's own priest once a year as a preparation for the reception of the Eucharist; and thirdly, the expectation of a higher standard of behaviour from clergy, which necessarily involved recounting examples of their contemporary shortcomings. These three areas feature prominently in the stories related in the Liber Exemplorum (often appearing in the same story), 60 years after the Council convened, and it is difficult not to see the influence of the one upon the other. While taking P.J. Dunning's point regarding a lack of sources for the implementation of the Council's decrees, it is argued here that this exempla collection does afford us a window into a world of belief in 13th century Ireland that might otherwise be hidden from us and "since it can safely be assumed that the substance of some of the material in this exempla collection was, indeed, preached", as Alan Fletcher reminds us, "onto things actually heard by medieval Irish audiences" (Fletcher 2001, p. 70).

\section{Tales Concerning the Eucharist}

Belief in the power of the Eucharist was a feature of medieval Catholicism long before the term transubstantiation came to be used to describe the transformation of the bread and wine into the body 
and blood of Christ. ${ }^{3}$ However, such belief could also lead to misappropriations of the sacrament. Thus, tales of Eucharistic miracles which occurred in response to such abuses functioned as stern warnings to congregations to avoid such desecration. The Liber Exemplorum features 19 stories concerning the Eucharist; 14 are organised together under the heading "Of Christ's body", while five more on the subject are scattered throughout the work. The Eucharistic stories can be organised thematically into four groups. The first grouping contains stories which stress the real presence of Christ in the Eucharist; these are Dauerwunder tales and nature miracles (see LE 10, 11, 12, 13, 16, 17-this refers to the enumeration of the individual tales in the collection, as found in Jones's edition. The term Dauerwunder is used to describe instances of the transformation of the host in some miraculous way; Christ himself is seen in the Eucharist, or real flesh and real blood spontaneously appear before the viewer, either as a prompt towards deeper faith, or as a dire warning to treat the host with appropriate reverence. See (Bynum 2007, pp. 83-84; Bynum 2011). For further examples and the broader historical context, see (Rubin 1991)). The second relates stories on the miraculous powers of the Eucharist; this category also includes stories on the malign power of the misused host (see LE 14, 15, 19, 20, 21, 22, 23, $24,97,99)$. The third grouping is tales which express the absolute necessity of the Eucharist for salvation (see LE 62, 69, 70, 122). The final category contains just a single narrative on the benefits of masses offered for the dead (see LE 18). By the time this exempla collection was being compiled, the mendicant orders had already acquired a reputation as active promoters of the doctrine of the transubstantiation of Christ's body and blood in the Eucharist (see Burr 1984); indeed, William H. Campbell observes that "by the late thirteenth century, theological discussion of the Eucharist had passed largely into the hands of mendicant theologians. Later, one of Wyclif's complaints about the friars was that they had spread belief in transubstantiation among the English people" (Campbell 2018, p. 137). Let us now examine some examples of how the teaching on transubstantiation was communicated by means of these tales.

In one Eucharistic tale in the Liber Exemplorum (LE 10), a woman in France took a consecrated host as if to give it to the sick (and the text adds "which the priest had carelessly given to her"), but instead, tied it up in the hood of a silk garment and placed it in a chest at home, kept almost as a relic. Some time afterwards the woman woke in the middle of the night to find a great light surrounding the chest. This continued for a number of nights until she called her husband and they examined the chest together to find the silk cloth containing the host that she had forgotten about and the cloth was soaked with fresh blood. Without delay they called the priest who un-wrapped the cloth to discover the host with the appearance of bleeding flesh on one side, with the letters of the host still embossed onto the skin, and of bread on the other. What is also interesting is how this miraculous host is treated after its discovery. It is taken in procession to the local church where huge crowds come to view and venerate the object, "not only from the city itself, but from neighbouring towns and villages, people who had either had doubts or who had completely turned aside from the teaching about the body of Christ". In this way, then, the miracle led to an increase in faith in Christ's real presence. However, tales such as this also fed into fears regarding the safety of the Eucharistic host, which was often in danger of being stolen from the church for use in rituals aimed at some worldly gain or other. It was for such reasons that the Fourth Lateran Council, in its 20th decree, mandated that "the Eucharist ... be kept locked away in a safe place in all churches, so that no audacious hand can reach [it] to do anything horrible or impious" (Tanner 1990, vol. 1, p. 244). The priest was to ensure that the Eucharist was protected, and the decree states that "if he who is responsible for their safe-keeping leaves them around carelessly, let him be suspended for three months; if anything unspeakable happens on account of his carelessness, let him be subject to graver punishment". The carelessness of priests with regard to the handling of the Eucharist is a relatively common theme in the Liber Exemplorum, bearing these

3 For a useful survey of some of the literature regarding the history of the Eucharist in Ireland in the period before 1200, see O’Donoghue (2011). 
fears out. C. Colt Anderson observes that Francis of Assisi himself had shown particular concern for the propriety with which sacred vessels should be treated, urging his brothers to guard against sullied chalices, corporals and altar-linens, and sternly warning them against leaving the consecrated host unsecured (Anderson 2010, p. 91).

A second type of narrative employed in the Liber Exemplorum to highlight the real presence of Christ in the Eucharist (and recounted widely during the period) is found in tales in which something in nature e.g., a plant, animal or insect, recognises the holiness of the host. These stories, writes Miri Rubin, "involve miraculous breaches in the rules of nature-evidence that Christ's body exerted which mere bread could not. Within this group there is a type in which simple beasts attest the divinity of the Host where blind humans do not" (Rubin 1991, pp. 122-23). This kind of story is exemplified in LE 16, which the author tells us originated in Germany. In this story a man was given the host, but "through lack of faith or disbelief", he placed it in the hollow of a tree in his garden. However, soon afterwards his circumstances changed and he became very poor and needy. Wondering at such a change in fortune, he returned to the hollow where he had buried the host and "when he looked inside he found a swarm of bees making honey as if they were in a hive. He brought his priest to see the spectacle and having broken and removed the shell of the hive [they] found in the middle a church made of wax; there was, however, not a single drop of honey. It had a tower and bells, with an altar and a chalice on it with corporals and a paten, and this so precious treasure ... was placed in the chalice as decently as the place allowed, not only through the work of little bees but also through the ministry of angels".

This story of eucharistically-attentive bees was a popular one; it appears in another version in an Irish language devotional collection from the 15th century entitled Liber Flavus Fergusiorum, which recounts how a priest bringing communion to the sick gets distracted by a swarm of bees and, eager to capture the swarm for himself, neglects the host and leaves it behind him. After going on his way and failing to capture the bees, he only later realises what he has done. Thereafter he spends a year in penance until an angel tells him where to find the lost host. The swarm of bees had recovered the Eucharist and brought it to their hive where they had built "a fair chapel of wax and an altar, and a mass-chalice and a pair of priests, fashioning them fairly of wax, to stand over the Host". The priest was instructed by the angel to bring people with him so that they, too, could witness the miracle and confess the real presence of Christ (see Gwynn 1905, pp. 82-83; Monaghan 2012, pp. 105-7).

While the above examples might be regarded as constituting instances of carelessness or neglect towards the host, other tales relate more specifically to a desire to use the host for explicit gain. One such tale (LE 99) concerns the misuse of the host for commercial purposes. The author of the Liber Exemplorum tells us that he heard this tale from "a friar whose truthfulness I do not doubt" and that it took place between Graiguenamanagh in County Kilkenny and New Ross in County Wexford. A man known as Palmer (because he had been to the Holy Land) owned a public house and one day bought a cask of wine to sell to his customers, but his wife thought he had paid far too much for it and that it would not realise a profit. Then one day one woman (who, it turns out, was a witch) approached her and asked "what would you give me if I ensure that you sell your wine as you wish?", and Palmer's wife came to an agreement with her. What the witch suggested was that the next time Palmer's wife took communion she should keep part of the host in her mouth until she got home and then put it in the cask of wine and she would thus get what she desired. Nevertheless, punishment was meted out to her, for when she eventually went to pour some of the wine out to customers there was no wine left in the cask. She investigated further by dipping her husband's pilgrim staff into it, but all that she could find was the fragment of the host. Repenting of her sin, she went immediately to her local priest for penance and he referred her on to one of the Franciscan friars (a certain Brother Donekan) who could better cater to her needs. Having confessed and received absolution, she returned to her tavern where she could then hear a whispering sound coming from the wine cask as if the wine were boiling. When she investigated further she could hardly stop the torrents of wine which emerged. The narrator of the story adds the following observation: "in this example the Lord clearly shows us the great power 
of holy confession ... for the wine lost through sin would never have been recovered through the merit of confession if the sin had not been forgiven through the merit of the woman's confession and repentance". However, the compiler, who states that he heard the story from Br Donekan himself, adds something else that is just as interesting. It is a cautionary note to would-be-preachers regarding how they might relate the story to a general audience:

Of course if anyone fears that in telling all the details of this story he may put it into the minds of evil or foolish persons to do something bad in describing the placing of the fragment of the sacred host in the cask, for men are prone to evil deeds, he may if he wishes or does not know any better, simply say that the witch taught the woman to do some foolish thing full of sin involving a wine-jar, which was greatly displeasing to God, and he therefore punished her sin most severely ... and thus one may proceed to the end without ever mentioning the holy Eucharist.

When dealing with sin, then, it was always a balancing act for both preachers and confessors to say enough about the sin so that its wrongness could be condemned with clarity, without at the same time inadvertently placing novel ideas in the minds of those who had never thought of such sinful possibilities.

The consecrated host was to be feared as well as venerated; it had the power to carry out great miracles, or if misused to exert terrible retribution. LE 20 is an account of a shipwrecked sailor, whose family offer the "saving viaticum" of the mass every day for his safe return. Following his rescue, the sailor recounts how every day at a certain time a figure came to him and gave him bread to eat. He later discovers that the visitor's arrival always occurred at the very same time that the mass was offered daily for him. The host, therefore, had great power, not just to save the eternal soul, but to aid the mortal needs of the living. The message here was simple: the Eucharist saves, in this case quite literally. Owing to this understanding, it was not uncommon for Christians in the later Middle Ages to attempt to harness the 'power' of the Eucharist for some worldly gain. Medieval Irish Christians, too, expected to reap some reward as a result of their Eucharistic devotion, and to receive it well in advance of Judgment Day. The well-known list of benefits for attending Mass, known as the merita missae, which appeared in many 15th century Irish manuscripts, offered something both for this world and the next: among the benefits to be received were the following: one would gain all one's needs that day (the implication is that this included both spiritual and practical needs); one would not lose the sight of one's eyes after viewing the host; one would not suffer sudden death that day (always helpful if one was not properly prepared); one would not suffer from indigestion; one's time in Purgatory would be shortened; and, perhaps the most novel of all, for the length of time one spent at Mass, one would not age; finally, one's venial (or less serious) sins would be forgiven each time one attended Mass. In the case of the latter, there is some evidence that this boon was taken to its extremes if the report of an English government official on the rebelliousness of the Irish, written as late as 1582, is to be believed: "And hearing Mass on Sunday or Holyday, they think all the week after they may do whatever heinous offence they like, and it is dispensed withal" (for these examples and more, see (Ryan 2013, pp. 63-73)).

For many Christians, the merita missae were specifically linked to viewing the Eucharistic host at the elevation, and thus benefits such as these often led to many people zealously exhibiting a kind of merit mania in rushing from church to church to catch as many Eucharistic consecrations as possible. One interesting feature of these lists as found in Irish manuscripts such as the 15th century Liber Flavus Fergusiorum and the Leabhar Chlainne Suibhne, an early 16th century book of devotion compiled for a Donegal noblewoman (see Ryan 2006, pp. 1-15), is a proviso contained within the title of each of the versions of the text. The merits are said to be available to all who attend Mass "ó tosach co deiredh" (from beginning to end), thus depriving those who wished to accumulate a quick spiritual fortune by running from church to church to catch as many elevations as they possibly could.

This emphasis on the importance of remaining for the entire length of the Mass, which was a feature of many Irish devotional collections later in the period can be found in the Liber Exemplorum 
in one of its tales (LE 62, which has its origins in Ireland, more specifically in Carrigtohill in Cork) in which the narrator tells us a virtuous and pious widow was "killed seven years ago". She was a woman of good repute, held in high esteem, and succeeded well at her business of brewing; on this account she was regarded as being wealthy, a perception which led to her home being broken into by an evil man who proceeded to murder her. A few days later the murdered widow appeared to her younger sister, and her sister asked her how she was getting on, for the dead woman seemed very sad. The woman explained to her sister that after she died she was "thrown into the fire". Her sister, shocked, enquired as to the reason for this unexpected turn of eternal affairs. The dead woman explained the cause of her misfortune as follows: "because on feast-days I used to leave church before communion" and, at that, she disappeared before her sister could ask her any more. Her sister came to the compiler of the Liber Exemplorum and asked him the significance of her words. The friar enquired as to whether her sister had had the habit of leaving mass before it was over. "Yes" replied the younger sister, "since no one could take care of her business, after the Elevation of the host she used to go home to ensure that none of the goods in the house were lost". It should be noted here that one of the merita missae cited in later Irish devotional collections promised that one would succeed in one's business affairs, but, again, this was dependent on one's remaining at Mass "ó tosach co deiredh". The friar-narrator of the 13th century tale further drives home his point when he explains:

Hearing this, I explained to her what she asked and told her that Christians must wait in church until the end of mass, because at the end the priest receives the body and blood of Christ on behalf of all the parishioners present, as if it were put in their own mouths; therefore everyone must remain until that moment, certain that by virtue of the sacrament, which the priest receives for everyone, every person of good will and devotion will receive spiritual refreshment for his soul.

Those of the laity who did receive the host, in response to the Fourth Lateran Council's decree that it should be received annually, needed to ensure that they were in a worthy state before doing so; a number of tales in the Liber Exemplorum communicate this point. One such tale (LE 14) tells how a man from near York received the Eucharist unworthily at Easter without first having availed himself of the Sacrament of Penance. The story relates how "after dinner that day he brought up all that he had eaten" and not only that day but for the succeeding days too; in fact, "he did not stop vomiting until he died". The pithy story immediately following it (LE 15) relates how a certain man from Devon "received the Eucharist on Easter Sunday" (here was a tale, then, designed to capture the attention of those whose reception of the Eucharist was most probably confined to that annual custom, laid out as a minimum requirement at Lateran IV). It states that "why, I do not know [he] kept it whole in his mouth". After doing so, he returned to his garden and "hanged himself with a noose because the wrath of God had come upon him". These sorts of warnings applied also to clergy who celebrated mass in a state of sin. The compiler also relates a story (LE 97) borrowed from Giraldus Cambrensis's Gemma Ecclesiastica, which tells of a priest "ensnared in the sin of the flesh" who celebrated the sacrament without repenting of his sin. When he reached for the consecrated host, it flew out of his hands; and the same thing happened at two subsequent masses. Having gone to the bishop, confessed his sin and completed a period of penance, he once again celebrated mass and, just before receiving the Eucharist, the three other hosts from the three earlier masses suddenly appeared before his eyes.

\section{Tales Concerning Sin and the Sacrament of Penance}

While annual reception of the Eucharist became a requirement for all Christians after the promulgation of decree 21 of the Fourth Lateran Council, this also meant prior reception of the Sacrament of Penance. This requirement would necessitate a programme of catechesis on how best to avail oneself of the sacrament, and thus at various periods throughout the later Middle Ages, efforts were made to inculcate the most desirable means of confessing sin. One of the most well-known was the "sixteen conditions for a good confession", which was promoted by figures such 
as Antoninus of Florence (1389-1459) and Angelus de Clavassio (1411-1495) who reproduced many earlier recommendations regarding the most appropriate approach to the sacrament. This list, which also features in a number of Irish manuscripts of the 15th and 16th centuries (Ryan 2006, pp. 1-15) called for the confession of sins to be "simple, humble, pure, faithful, and frequent, unadorned, discreet, willing, ashamed, whole, secret, tearful, prompt, strong and reproachful and showing willingness to obey" (Ó Clabaigh 2002, pp. 122-23).

A similar preoccupation with the proper confession of sin can be seen in some tales from the Liber Exemplorum. One of the most striking (LE 95) concerns a man who encountered the devil in the form of a dreadful beast while he was travelling at night from one town to another. Transfixed by fear, he took the axe he had with him and drew a circle around himself, and marked it with the signs of Christ's cross, but he still feared that because of his sins he would be delivered into the devil's power. So, almost like the crew of a sinking vessel who try desperately to offload their cargo to buy time, this man attempted to offload his sin. Realising that he did not have a priest at his disposal, he pledged to abandon his sinful life and began to recite his sins out loud to God. Just as he did, a wall immediately rose up from the ground around him and, with every confessed sin, the wall became higher so that "when his confession was complete it was so high all around him that he stood safely inside it as if in a strong tower". Yet he still did not feel safe in his heart because the devil hurled himself at the wall repeatedly in an effort to scale it or to bring it down. Finally, when the wall had reached its full height, the devil reached the top of it and glared down at him, but could do no more. The narrator then draws the lesson from it:

So you now see, Christian, how much power true confession, made to a priest as ordained by the Church, has against the devil when this confession, made to God in the midst of a field, was so powerful against him. Indeed this confession had no power except through the pious wish and intention to confess his sins in the due fashion and completely change his manner of life according to the will of God ... this happened near Dublin. ${ }^{4}$

One of the later "sixteen conditions" for a good confession was that the confession be "whole" or "complete", that is, without holding anything back. Yet, the temptation was to do precisely that; namely, to hold back whatever was one's most shameful sin. One tale in the Liber Exemplorum (LE 100) deals precisely with this issue. It tells of a "woman who, while devout in prayer and in giving alms and in many other good works, in her shame, always concealed a single sin which she had committed in her youth". When she was near death a troop of demons gathered around the cell of an anchorite and asked each of them what work they were doing. One boasted that the very next day he would have the soul of a woman whom everyone had considered holy. Revealing how he would do this, he told the others that there was one sin which she had never confessed and he added "and when she does want to confess I will stop up her mouth so that he sin cannot be laid bare to the priest". However, the demons had not chosen the location for their meeting very well, because the anchorite heard all of this and proceeded to send for the priest to tell him everything she had learned. The priest duly visited the woman and started to speak of confession and, seeing that she was close to death, prompted her: "did you not commit such a sin in your youth which you never revealed to me in confession?" (this references the fact that Lateran IV, canon 21, expected all the faithful to "confess all of their sins in a faithful manner to their own priest ... ". Emphases mine. See (Tanner 1990, vol. 1, p. 245). Thus did he coax the woman to confess her fault "and her sin was immediately washed away in a great flood of tears which continued until she breathed her last". The narrator goes on to add: "See how

4 On some of the theological debates pre-1200 regarding the sufficiency of contrition for sin to be forgiven (apart from recourse to a priest in the sacrament), and the contribution of Gratian in insisting that both confession and satisfaction for sin were an integral part of the Christian tradition, see Goering (2008, pp. 222ff). Also for the preoccupation with confession and contrition in Lanfranc of Canterbury (c. 1005-1089), who was a great critic of many practices within the Irish Christian church, see Bériou (1986). 
great is the strength of repentance and confession, through which a sinner may be taken so quickly from the devil".

Stories such as the one above communicated something of the precarious nature of one's position if one remained in an unshriven state owing to the postponement of a recourse to the sacrament or the omission of one's full list of sins when there. LE 110 is a particularly dramatic example and concerns a man who promises to his friar brother that he will give up his concubine and finally confess his sin; and indeed he agrees that he will do before a certain date. However, ultimately, he is not afforded the opportunity to do so, for he chokes to death on a small piece of food at a feast with his friends and, the narrator notes, "the wretched man died suddenly in their midst and received his judgement in the fires of Hell before the day which he had fixed to lay aside his $\sin ^{\prime \prime}$. The moral was clear: repent now, for death may come suddenly, unannounced and sooner than you think. The stakes could not have been higher. The acknowledgment that to delay the confession of sin could imperil one's salvation is captured in an Irish bardic religious poem composed by Gofraidh Ó Cléirigh, whose dates are uncertain (but the poem cannot have been composed later than the third quarter of the 14th century). It begins with the poet acknowledging that "I am slow to roof my house; soon I shall hear the coming shower; the world is no lasting house for him who would fain be dry" and proceeds with the poet admitting that "I love the women of the world and its banquet, (yet) short is its spell" (McKenna 1940, p. 138). Another exemplum in the collection (LE 44) makes a similar point regarding the necessity of confessing early, but in this instance there is a happier ending - of sorts, at least. The compiler explains that he heard the tale from a friar who was visiting Paris and who had been present at the siege of Seville in 1247-1248. He told of how a young man travelling with the army of King Ferdinand of Castile, having failed to confess his sins to a priest when the army had camped for three days to attend to matters such as this, now begged a friar to hear his confession once they were on the move again. Perplexed at the man's insistence, and wondering why he had not taken the opportunity before now, the friar enquired of the man his reasons before eventually agreeing to hear his confession. The young man explained that he had been visited by a beautiful woman who had warned him on three occasions that he would die that very day. The friar wondered whether this might be a vision of the Blessed Virgin and asked the man whether he had any special devotion to her, to which he replied "no". However, upon reflection, he admitted that he had learnt from his mother the custom of reciting an Ave Maria each time he heard the name "Mary". The tale ends (happily) with the young man going into battle and getting killed that day by a huge stone from a faulty siege machine, an incident which the narrator credits with "free[ing] his soul from the mouth of the lion and most mercifully prepar[ing] him for life eternal" (for further discussion of warnings concerning the afterlife in the Liber Exemplorum, see (Shanahan 2016)).

The concern with full confessional disclosure could be found elsewhere in 13th century Ireland, apart from the preaching collections of friars. A 13th century Irish bardic religious poem raises the same issue, but using different imagery. The poet, Giolla Brighde Mac Con Midhe, concludes that "the best recipe for seeking heaven is confession and repentance". In imaginative fashion, he speaks of the work of the ploughman who turns the soil. He points out that while an upturned clod with its grass-side showing might be more aesthetically pleasing to the eye, nevertheless no new seed can grow from it. Likewise with confession: unless one is willing to reveal the darker side of oneself in its entirety, no new growth can begin:

The loamy upper sod is confession that conceals nothing; the green, grassy, overgrown thicket is the complacent and loud-mouthed man ...

Confession with its grass showing is a creation pleasing to the eye but fraught with filth; the craftsman of the elements is displeased with it when the earth-side is not uppermost. 
Let us throw up the brown earth, let us hide the side of the grass, fair to look upon; let us, moreover, plant seed-what point would there be in ploughing without that? ${ }^{5}$

The longevity of such concerns can be seen in the fact that a tract on the Sacrament of Penance compiled by Aodh Mac Aingil, an Irish Franciscan friar working at St Anthony's College, Louvain, and published in 1618, thought it necessary to reiterate the point: "It is certain that whoever fails to confess a mortal sin, however terrible, out of shame, will not [only] forfeit the benefit of confession but will add a new mortal sin to the sin, which was on him, before coming to confession" ((Mac Aingil 1952, p. 80), my translation; For a broader discussion of the longevity of late medieval Irish concerns regarding the proper disposition when approaching the Sacrament of Penance, see (Ryan 2014, pp 124-34)).

\section{Tales Concerning the Behaviour of Clergy}

As seen above, the Fourth Lateran Council placed significant emphasis on the reform of the morals and behaviour of the clergy. Here follow some stories from the Liber Exemplorum, which touch on this theme, often with a sub-theme of the wayward cleric's devotion to the Virgin Mary. One such tale (LE 40) concerns a lustful cleric from the city of Chartres in France, who was widely known to be ensnared by carnal desire (a subject which is given its own decree at the Fourth Lateran Council—canon fourteen-on punishing clerical incontinence). Yet the cleric had a devotion to the Virgin Mary and was fond of praying the Ave Maria. When he died, having been "killed by his enemies" (which suggests that his indiscretions were wide indeed), his fellow clergy buried him as they saw fit, outside of the churchyard and consecrated ground. Yet 30 days the Virgin appeared to one of them and enquired as to why they had buried her chancellor outside of the churchyard "for he used to serve me most faithfully and often made his salutation at my altar. Go immediately and take his body from that shameful place and bring it into the churchyard". When they did this and opened his tomb they found a most beautiful flower in the cleric's mouth and his tongue, which so often praised the Virgin, had been preserved from any decomposition. A similar tale (LE 52) recounts how a lustful monk left his monastery at night-time to meet a woman and, while crossing a bridge, was drowned by demons. However, the monk had been accustomed to say an Ave Maria whenever he passed a statue of the Virgin Mary and, on that account, Mary sought his body from the demons, he was dragged from the river and restored to health. In another example (LE 205), a monk agrees to a liaison with a girl in an orchard, but draws back when he asks the girl if anybody can see them and she replies "no one except God". While these stories ultimately turn out well for the clerics in question, the reality of reprehensible clerical conduct was nevertheless acknowledged.

One might wonder whether such salacious tales were always preached just as they appear in exempla collections such as the Liber Exemplorum. There is reason to suppose that some judicious redaction was often employed on the part of the preacher. For instance, in a story from the collection (LE 154), which is taken from Gregory the Great's Dialogues, we hear of a monk who, while he appeared to fast with his brethren, instead ate in secret. However, he soon became ill and was close to death at which point he admitted to his community that "when you thought I was fasting with you I was eating in secret; and lo! I am handed over as food to the dragon whose tail has bound my knees and feet; indeed it has put its head inside my mouth and has sucked out and stolen my breath". He died shortly afterwards. In any case, the narrator adds the following commentary to the story:

Although this story refers to a monk, if it is used in the form in which it is written it will cause scandal among the religious and not be very edifying to the people. Some slight changes can be made while preserving the essential truth of the story; then it will edify the people without causing offence to anyone. Clearly the monk was a man and therefore the whole story can be told as concerning a certain man ... 
You may therefore tell the story in this way: Gregory tells how a certain man used to eat when he should have been fasting...

If the example is used in this way the truth will be preserved and the people will be shaken with fear without giving offence to anyone. If the sermon is preached before religious, the example will make an excellent attack on hypocrisy if used in its original form.

A similar concern for preserving propriety of language in preaching can be seen in a tale on humility (LE 165), which is taken from the Gemma Ecclesiastica of Giraldus Cambrensis, in which Alexander of Macedon asks Dionysius the philosopher: "What was I? What am I? What will I be?" and the philosopher replies: "vile sperm, a vessel of dung and food for worms". The compiler once again comments:

Let the preacher take care to use appropriate words. He may say "mud" for "dung" and "a thing of small value" for "vile sperm". For if he says that when you were conceived you were a thing of small value, it will be understood well enough. Let us therefore take care to use these or other similar words in matters of this sort.

Issues of clerical conduct were not solely related to that of sexual sin; LE 18 recounts the story of a monk who became ill and was approaching death, at which point his confrères discovered that he had been holding back three gold pieces for himself from the common monastic fund. The story ends well after the celebration of thirty masses for the monk's soul after his death; however, the theme of the story dovetails with the sixty-sixth decree of Lateran IV, which deals with the avarice of clerics.

\section{Conclusions}

Taking our cue from concerns expressed in some key decrees of the Fourth Lateran Council of 1215 , we have seen how these have come to be expressed some 60 years later through the medium of exempla found in a Franciscan preaching manual produced in Ireland. While very few of the late medieval laity would have cause to read the canons of the Fourth Lateran Council, they would certainly have received the gist of the most pertinent of its decrees for their daily lives, namely those relating to the nature of the Eucharist and the requirement to receive it annually, after recourse to the Sacrament of Penance. It is clear, too, that the necessity of the reform of the behaviour of the clergy was also a topic of some importance and this is evident in the number of times they feature in these tales-and rarely in a flattering light.

As noted above, the Fourth Lateran Council had laid down strict regulations for clergy and had instructed that they avoid taverns, drinking contests and games of dice- but it had not, as far as I am aware, pronounced on the subject of wrestling. However, the Liber Exemplorum did in tale LE 191. This one, the compiler admits, he received from a Dominican called Brother Bartholomew. A priest in England, in his own day, a strong and easy-going fellow, was given to a life of pleasure, which included an inordinate interest in both wrestling and dances. Every year on the eve of his church's feast day he would say Matins at the start of the night and then head out to watch both pursuits. On one occasion, however, he saw two of the foulest demons sitting on top of the two wrestlers operating their limbs as if the wrestlers were puppets. The priest became afraid and moved on to the dance at which he saw something similar: two demons sitting on each of the men and women. The priest hurried home and went to bed terrified and when he awoke he found that no hair was left on his head, nor nails or skin on his body and he was afflicted with illness and was unable to celebrate mass for a year afterwards. The compiler adds a ring of authenticity to the tale when he explains that, "a brother of their order, who was also the son of the priest, told these things to the friar mentioned above, who told me".

With tales such as these did the ideals set down at arguably the most significant of the medieval councils take on a form that could quickly and easily be communicated in late 13th century Ireland, and in a manner that would surely not be forgotten in a hurry. While the exempla found in the Liber Exemplorum should not, themselves, be regarded as exclusively responding to the legislation of 
Lateran IV (for many of them predate the Council in origin), yet their employment (and, in some cases, redeployment) in the context of the cura animarum of late 13th century Irish congregations should be seen as reflecting the broader theological, canonistic and pastoral concerns of the 12th and 13th century reform movements which found their most concrete expression in the Fourth Lateran Council of 1215.

Author Contributions: This article arises from the respective research of both Salvador Ryan and Anthony Shanahan. Salvador Ryan presented early versions of this material at a guest lecture delivered at the Australian Catholic University, Brisbane, Australia, on 11 April 2016, a conference paper for the Catholic Historical Society of Ireland Conference on 10 September 2016, and a fuller version, more recently, at the Mícheál Ó Cléirigh Institute, University College Dublin on 23 February 2018 (it should be noted that no funding was received in respect of any of the aforementioned lectures). Anthony Shanahan completed a Masters dissertation entitled "The Liber Exemplorum Ad Usum Praedicantium: A Window into 13th Century Popular Religious Ideas and Practice" as part of a Masters in Theology (History of Christianity) at the Pontifical University, St Patrick's College, Maynooth, where he graduated in November 2017. The sections of the article incorporating the categorisation of stories and those dealing, in particular, with visitations (with warnings) from the afterlife draw from Anthony Shanahan's work, on which he has also recently published (see the Death and the Irish volume); likewise the discussion of Dauerwunder tales and nature miracles. The arguments contained in this article arise from extended periods of discussion between both authors concerning the historical value of this remarkable source as a window into the implementation of the Fourth Lateran Council in late-thirteenth-century Ireland. Salvador Ryan wrote the paper.

Conflicts of Interest: The authors declare no conflict of interest.

\section{References}

\section{Primary Source:}

Durham Cathedral Library. Liber Exemplorum. MS B.IV.19.

\section{Secondary Sources:}

Anderson, C. Colt. 2010. Ritual Purity and Pastoral Reform in the Thirteenth Century. In A Companion to Pastoral Care in the Late Middle Ages (1200-1500). Edited by Ronald J. Stansbury. Leiden: Brill.

Bériou, Nicole. 1986. La Confession dans les Écrits Theologiques et Pastoreaux du XIIIe Siècle. In L'Aveu: Antiquité et Moyen Âge. Rome: École Française de Rome.

Birkett, Helen. 2006. The Pastoral Application of the Lateran IV Reforms in the Northern Province, 1215-1348. Northern History 43: 199-219. [CrossRef]

Bremond, Claude, Jacques Le Goff, and Jean-Claude Schmitt. 1996. L'Exemplum, 2nd ed. Turnhout: Brepols.

Burr, David. 1984. Eucharistic Presence and Conversion in Late Thirteenth-Century Franciscan Thought. Transactions of the American Philosophical Society 74: 1-113. [CrossRef]

Bynum, Caroline Walker. 2007. Wonderful Blood: Theology and Practice in Late Medieval Northern Germany and Beyond. Philadelphia: University of Pennsylvania Press.

Bynum, Caroline Walker. 2011. Christian Materiality: An Essay on Religion in Late Medieval Europe. New York: Zone Books.

Campbell, William H. 2018. The Landscape of Pastoral Care in Thirteenth-Century England. Cambridge: Cambridge University Press.

D'Avray, David L. 1985. The Preaching of the Friars: Sermons Diffused from Paris before 1300. Oxford: Oxford University Press.

Dunning, Patrick. J. 1961. Irish representatives and Irish ecclesiastical affairs at the Fourth Lateran Council. In Medieval Studies Presented to Aubrey Gwynn. Edited by John Anthony Watt, John B. Morrall and Francis Xavier Martin. Dublin: C. Ó Lochlainn.

Flanagan, Marie Therese. 2013. The Transformation of the Irish Church in the Twelfth Century. Woodbridge: The Boydell Press.

Fletcher, Alan J. 2001. Preaching in Late Medieval Ireland: the English and Latin Tradition. In Irish Preaching 700-1700. Edited by Alan J. Fletcher and Raymond Gillespie. Dublin: Four Courts Press. 
García y García, Antonio, Peter Gemeinhardt, Georg Gresser, Thomas Izbicki, Atria Larson, Alberto Melloni, Jürgen Miethke, Kenneth Pennington, Burkhard Roberg, Riccardo Saccenti, and et al. 2013. The General Councils of Latin Christendom: From Constantinople IV to Pavia-Siena (869-1424). Corpus Christianorum, Conciliorum Oecumenicorum Generaliumque Decreta 2.1; Turnhout: Brepols.

Goering, Joseph. 2008. The Scholastic Turn (1100-1500): Penitential Theology and Law in the Schools. In A New History of Penance. Edited by Abigail Firey. Leiden: Brill.

Gwynn, Edward John. 1905. The Priest and the Bees. Ériú 2: 82-83.

Izbicki, Thomas M. 2015. Sin and Pastoral Care. In The Routledge History of Medieval Christianity, 1050-1500. Edited by Robert Swanson. London and New York: Routledge.

Jones, David. 2011. Friars' Tales: Thirteenth-Century Exempla from the British Isles. Manchester: Manchester University Press.

Mac Aingil, Aodh. 1952. Scáthán Shacramuinte na hAithridhe. Edited by Cainneach Ó Maonaigh. Dublin: Dublin Institute for Advanced Studies.

McKenna, Lambert. 1940. Aithdioghluim Dána. Dublin: Irish Texts Society.

Monaghan, Evie. 2012. Blessed Bees. In Treasures of Irish Christianity: People and Places, Images and Texts. Edited by Brendan Leahy and Salvador Ryan. Dublin: Veritas.

Ó Clabaigh, Colmán N. 2002. The Franciscans in Ireland, 1400-1534. Dublin: Four Courts Press.

Ó Clabaigh, Colmán. 2012. The Friars in Ireland, 1224-1540. Dublin: Four Courts Press.

Ó Corráin, Donnchadh. 2017. The Irish Church, its Reform and the English Invasion. Dublin: Four Courts Press.

O'Donoghue, Neil Xavier. 2011. The Eucharist in Pre-Norman Ireland. Notre Dame: Notre Dame University Press.

Ohst, Martin. 1995. Pflichtbeichte. Untersuchungen zum Busswesen im hohen und späten Mittelalter. Tübingen: Mohr Siebeck.

Reeves, Andrew. 2013. The Cure of Souls is the Art of Arts: Preaching, Confession and Catechesis in the Middle Ages. Religion Compass 7: 372-84. [CrossRef]

Reeves, Andrew. 2015. Religious Education in Thirteenth-Century England: The Creed and Articles of Faith. Leiden: Brill. Rubin, Miri. 1991. Corpus Christi: The Eucharist in Late Medieval Culture. Cambridge: Cambridge University Press. Ryan, Salvador. 2006. Windows on Late Medieval Devotional Practice: Máire Ní Mháille's ‘Book of Piety' (1513) and the World Behind the Texts. In Art and Devotion in Late Medieval Ireland. Edited by Rachel Moss, Colmán Ó Clabaigh and Salvador Ryan. Dublin: Four Courts Press.

Ryan, Salvador. 2013. Merita Missae: The Eucharist and the Lived Reality of Irish Christians in the Late Medieval and Early Modern Periods. In Proceedings of the International Symposium of Theology: 50th International Eucharistic Congress, 2012. Dublin: Veritas.

Ryan, Salvador. 2014. Penance and the Privateer: Handling Sin in the Bardic Religious Verse of the Book of the O'Conor Don. In Christianities in the Early Modern Celtic World. Edited by Tadhg Ó hAnnracháin and Robert Armstrong. Basingstoke: Palgrave Macmillan.

Shanahan, Anthony. 2016. Visions of the Afterlife in the Liber Exemplorum. In Death and the Irish: A Miscellany. Edited by Salvador Ryan. Dublin: Wordwell.

Tanner, Norman P. 1990. Decrees of the Ecumenical Councils. Washington: Georgetown University Press.

Tanner, Norman. 2000. Pastoral Care: The Fourth Lateran Council of 1215. In A History of Pastoral Care. Edited by Gillian R. Evans. London and New York: Cassell.

Warren, Wilfred Lewis. 1997. Church and State in Angevin Ireland. Chronicon 1: 1-17.

Welter, Jean-Thiébaut. 1927. L'Exemplum dans la littérature religieuse et didactique du Moyen Age. Paris: Occitania. Williams, Nicholas J. A. 1980. The Poems of Giolla Brighde Mac Con Midhe. Dublin: Irish Texts Society.

(C) 2018 by the authors. Licensee MDPI, Basel, Switzerland. This article is an open access article distributed under the terms and conditions of the Creative Commons Attribution (CC BY) license (http://creativecommons.org/licenses/by/4.0/). 